第 7 表に示す如く長く蒸焦すると $a$ は逐に 0.9 位の値となるっ 是はスっアレンのような長い分子の炭化水 素の時に樱田氏(本誌,昭和 $8,36,1487$ )が見出した數值と殆ど一致し，此酳酸棫維素はスクアレンと同樣の形 を存するのではないかと考へられるのであるが，a の數值か同一でも必ずしも同形であるとは瞇言出來ない。

$\varphi$ の值は蒸煮と共に減少して行く，これは粒子が分裂して共結果溶劑の機栈的抱存が小となつた事に体るる のであらら。

蒸煮と共に耐熱度が多少惡くなるのは粒子が小となると共に表面栍が大となる事に關係するものであらう。 笔素量も僅小乍ら減少する。

第 6 圖は是等の結果をまをめて方した。
3）總
括

i）硝化綿を $130 \sim 135^{\circ} \mathrm{C}$ で $0 \sim 10$ 時間蒸惹して，共粘度變化，耐熟度變化及窒素量の變化を調查した。

ji）粘度湘定值より贸田氏の方法で形狀電荷俰數 $a$ 及比容积 $\varphi$ を求めた。形狀宅荷倸數 $a$ は蒸煮と共に 比較的急激に減少して一定値に近づき，比容稆 $\varphi$ は連續的に減少する。

iii）耐爇度及窒素量は蒸煮と其に減少する。

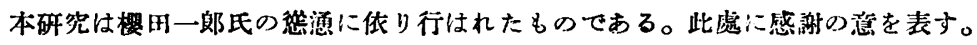

（果京工業試驗所第 2 部油脂研究宝）（昭和 10 年 2 月 13 日受理）

\title{
95.ザク口種子油中に存在する新脂肪酸 (エレオステアリン酸の新立體異性體)に就て
}

外山 修之・土屋知太郎

暴に余等 (東工試報，27，11 號）はザクロ (安不榴) Plinica Granatum, L. の種子油より其脂肪酸の主成 分として融點 $43 \sim 43.5^{\circ} \mathrm{C}$ の新脂肪酸を分離し且該脂肪酸が保存中に容易に $\beta$-エレオステアリン酸に轉位する 事惯によりて該脂肪酸はェレオステアリン酸の立啯異性體なることを知れり。今包余等は更に別の試料油を

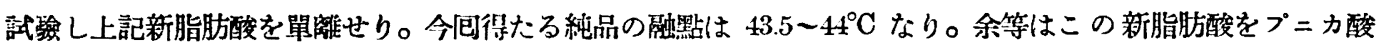
(Punicic acid; Punicasäure) 命名す。プニカ酸はエレオステアリン酸の 立體巽性體なるを以てエレオステ アリン酸と同じ位置に二重結合を有することは既に明白なるも, 念の䉆め余等は今包得たるプニカ酸をオデ リシスに附して分解生成物を檢索せり。其結果は以下に記載寸るが如くプニカ酸の分解生成物として正吉草酸 $\mathrm{C}_{5} \mathrm{H}_{10} \mathrm{O}_{2}$ 及アゼライン酸 $\mathrm{C}_{9} \mathrm{H}_{16} \mathrm{O}$ 、を確認し猊後酸 $\mathrm{C}_{2} \mathrm{H}_{2} \mathrm{O}_{4}$ 及グリオキザル $\mathrm{C}_{2} \mathrm{H}_{2} \mathrm{O}_{2}$ す存在するすのと 認められたり。又プニカ酸メチルをオジノリシスに附したるに楽分解生成物中にアゼラインアルデヒド酸メチ ルエステル $\mathrm{C}_{10} \mathrm{H}_{18} \mathrm{O}_{3}$ 及アゼライン酸モノメチルェステル $\mathrm{C}_{10} \mathrm{H}_{18} \mathrm{O}_{4}$ を検出せり。從てプニカ酸は $\mathrm{CH}_{3}$ ・ $\left(\mathrm{CH}_{2}\right)_{3} \cdot \mathrm{CH}=, \quad=\mathrm{CH} \cdot \mathrm{CH}=(2$ 㑬 $),=\mathrm{CH} \cdot\left(\mathrm{CH}_{2}\right)_{7} \cdot \mathrm{COOH}$ なる原子䀳を有し其構造式は次の如くにして エレオステアリン酸と同一なることを知る。

$$
\mathrm{CH}_{3} \cdot\left(\mathrm{CH}_{2}\right)_{3} \cdot \mathrm{CH}=\mathrm{CH} \cdot \mathrm{CH}=\mathrm{CH} \cdot \mathrm{CH}=\mathrm{CH} \cdot\left(\mathrm{CH}_{2}\right)_{7} \cdot \mathrm{COOH}
$$

實驗之部

1.ザクロ種子”油よりプニカ酸の骂離並に其 2〜3の性将

ザクロ種子 (静岡憬賀茂郡産) を粉碎し之をェーテルにて抽出し, 得たるエーテル抽仙油を不油エーテルに 
て處理して微量の不溶解物を除き石油エーテル可溶部を捕集せり。斯くして得たる油（收率約 11\%）は橙黄色 液體にして下記性質を有せり（ザクロ種子油の一般性狀に就ては猛前回報告を照せらるべし）。

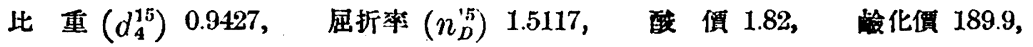
沃素價（ウィイス法） 169.7

本油は屈折率の高き點に於て桐油に似たり。又本油は乾燥性强くガラス板に整布せる薄首は $100^{\circ} \mathrm{C} に$ 於て 15 分間にて乾燥せり。但し乾燥皮膜は不透明にして平滑ならず。

本油より常法によりて䑚肪酸 $60 \mathrm{~g}$ を㓶取し之を $95 \%$ アルコール 600 cc に溶解し之に醋酸、グネシウム $3.4 \mathrm{~g}$

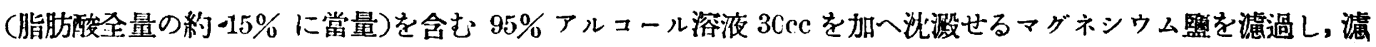
液に含まるつ脂肪酸を捕策して $80 \%$ アルコールより 2 回再結晶し融然 $43.5 \sim 44^{\circ} \mathrm{C}$ の小片狀結晶 (A) 約 $25 \mathrm{~g}$

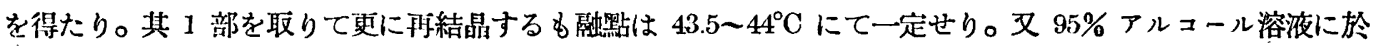

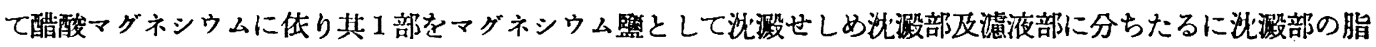

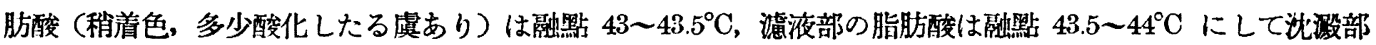
の脂肪酸も再結晶後, 融嚸 $43.5 \sim 44^{\circ} \mathrm{C}$ となれり。此等の實驗結果により上記融照 $43.5 \sim 44^{\circ} \mathrm{C}$ の結晶(A)を以 て純粹なるプニカ酸と見做し下記恒數を測定せり。其沃素價か計算數よりも著しく低き䬯はエレオステアッン 酸の場合に於けると同梯なり。

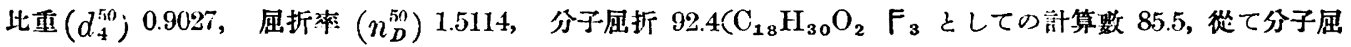

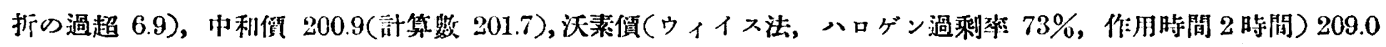
(社算數 673.7)。

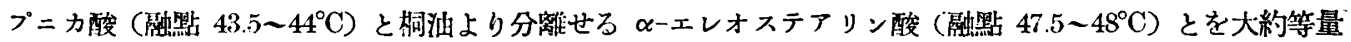
宛混合したるに其融點は約 $35^{\circ} \mathrm{C}$ に降下せり。叉プニカ酸と $\beta$-エレオステアリン酸（ $\alpha$ ーエレオステアリン酸

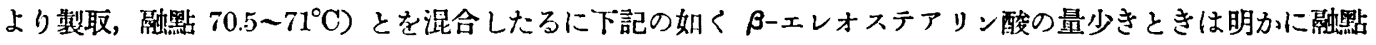
降下を示せり。

$\begin{array}{cc}\text { プ カ酸 } & \beta \text {-ェレオステフリン酸 } \\ 85 \% & 15 \% \\ 80 \% & 20 \% \\ 60 \% & 40 \%\end{array}$
混合物の蟨點
$39.5 \sim 40^{\circ} \mathrm{C}$
$40 \sim 42.5^{\circ} \mathrm{C}$

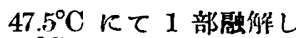
$52^{\circ} \mathrm{C}$ にて透明となる

プニカ酸の不油エーテル溶液に㮂素を添加して得たる白色固體の臭化物は不油エーテルより再結晶後, 融照

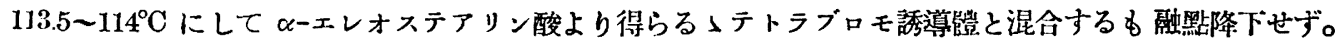

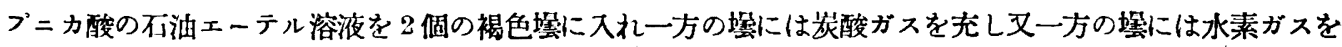
允して夫々密栓し約 1 週間保存したるに岑酸ガスを充したるものは多量の板狀結晶を析出せり。この結晶は融

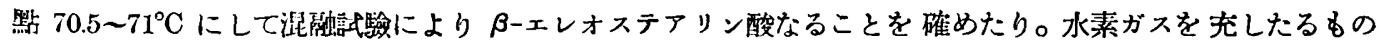
は更に長期間圆きたるも $\beta$-エレオステアリン酸の結晶を析出せざりき。又プニカ酸に䚀化水素を含有するメ

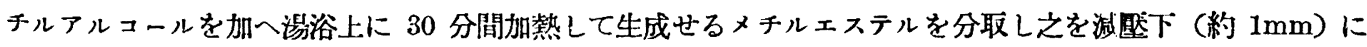
蒸溜して溜出せる部分を捕集し殓化して遊離の脂肪酸となし $95 \%$ アルコールより再結晶したるに瀜點 70.5〜 $71^{\circ} \mathrm{C}$ のーエレオステアリン酸を得たり。此等の實驗結果によればプニカ酸は容易に其立體巽性體なる $\beta$-エ レオステアリン酸に轉位するものなり。 


\section{2. プニカ酸のオジノリシス}

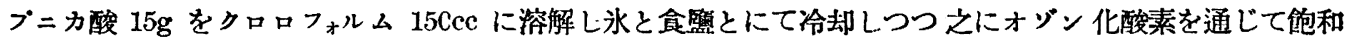

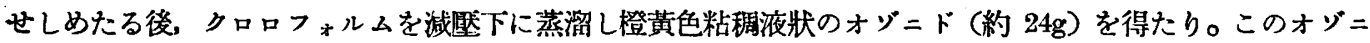
ドに水 $150 \mathrm{cc}$ を加へ湯浴上に加熱して分解せり。其際生じたる揮發性分解生成物（A）は水を入れたるフラス コ（a）及水酸化バリウム溶液を入れたるフラスコ(b)に於て捕集せり。オジニドは分解と共に大部分水に溶解 せるも1部は赤橙色油狀物質 $(\mathrm{D})$ となりて分離せり。此油狀物質を除きたる水溶液はエーテル約 1 l にて處 理しエーテル抽出物 (B) と水溶液 (C) とに分離せり。斯くして分解生成物を A, B, C, D の 4 部に分ちて各 部を檢索せり。

揮發性分解生成物 (A) フラスコ (a) の水溶液はファシン亞硫酸溶液を紅變してアルデヒド 反應を呈したる

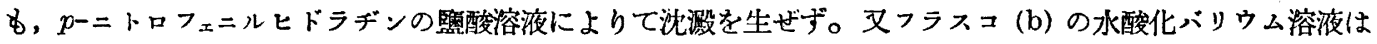
炭酸バリウムの沘澱を微量 (プニカ酸に對し約 $0.7 \%$ ) 生ぜり。從てオジニドの分解により微量の無水炭酸を 生じたることを知る。この微量の無水炭酸は主として後に記战する葆酸及グリオキザルの第 2 次的分解に依り て生じたるものなるべし。

エーテル抽出物 (B) $9.8 \mathrm{~g}$ あり。之を不油エーテル $300 \mathrm{cc}$ にて處理して可溶部 $3.7 \mathrm{~g}$ と不溶部 $6.1 \mathrm{~g}$ とに分 別せり。

石油エーテル可溶部を蒸溜して $150^{\circ} \mathrm{C}$ 以下の溜分及 150 〜 $190^{\circ} \mathrm{C}$ の溜分を捕集したるに $150^{\circ} \mathrm{C}$ 以下の溜分

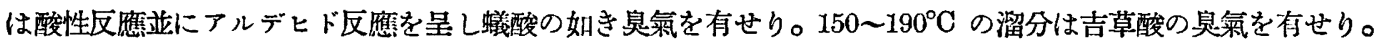
此溜分にチオニルクロリドを作用せしめて監化物となし之を强冷せる濃厚アンモニア水中に滴下し次に水を加 へて生じたる少量の不溶解物を除きアンモニア溶液をエーテルにて抽出しェーテル抽出物を更に石油エーテル より再結晶して鱗片狀の結晶を得たり。融點 $105 \sim 106^{\circ} \mathrm{C}$, 之をカールバウム製正吉草酸より同樣にして製取 せる融點 $105 \sim 106^{\circ} \mathrm{C}$ の正吉草酸アミドと混合するも瀜點降下せず (Beilstยin, Erstens Ergänzungswerk, Bd. II, S. 131 に據れば正吉草酸了ミドの融點は $106^{\circ} \mathrm{C}$ )。

石油エーテル不溶部は之をアルカリ性過マンガン酸カリ溶液にて酸化したる後酸性となし酸化生成物を一旦 エーテルにて捕集し次に之を熱湯にて抽出し抽出液を冷却して多量の板狀結晶を得たり。中和價 $594.6\left(\mathrm{C}_{9} \mathrm{H}_{16}\right.$

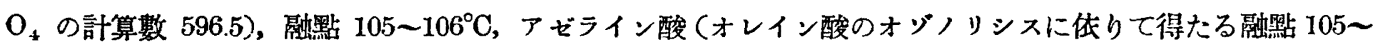
$106^{\circ} \mathrm{C}$ のもの) と混合するも融點降下せず。

水溶液 (C) 上記エーテル抽出物 (B) を除きたる水溶液の 1 部をアンモニアにて中和し嶟化カルシウム溶

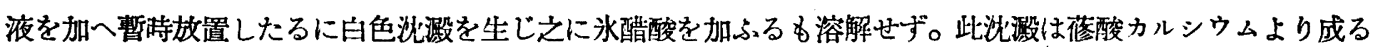
るのと認めらる。唒水溶液の $\ell$ 部に $p$-ニトロフェニルヒドラヂンの $50 \%$ 酳酸溶液を加へて多量の紅色沈澱

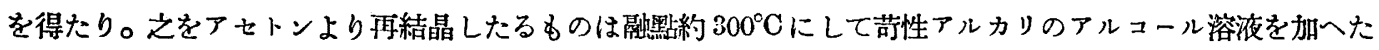
るに溶解して青色を虽したるを以て恐らく未精幣のグリオキザル誘導澧と思はる(Beilstein, Erstens Ergän-

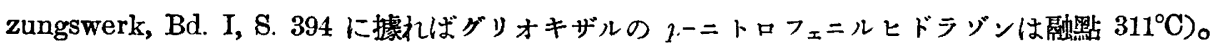

油狀物質 (D) $1.5 \mathrm{~g}$ あり。之にアルカリ性過マンガン酸カリ溶夜を加へて加熱酸化し次に酸性となして酸

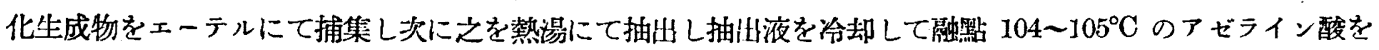
得たり。 
3. プニカ酸メチルのオジノリシス

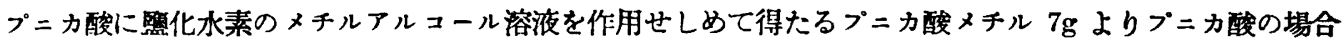
と同榚にしてオゾニドを製取し之に水を加へて湯浴上に加熱して分解せり。分解生成物より水に溶解せざる油 狀の部分 (4g) を分取し之をェーテルに溶解し炭酸ッーダ溶液にて處理して酸性物質をッーダ整となしエーテ

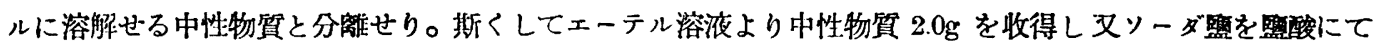
分解して酸性物質 $2.0 \mathrm{~g}$ を收得せり。

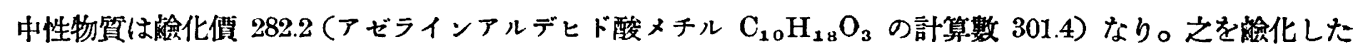
る後, 冷アルカリ性過マンガン酸カリ溶液にて酸化し次に酸性となしエーテルを用ひて酸化生成物を捕集し头

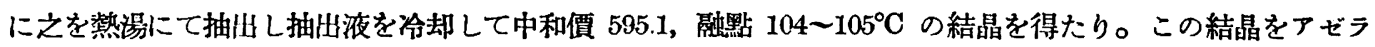
イン酸の純品（融熙 105～106ㅇ）と混合するも融點降下せず。此等の實驗結果によれば最初の 中性物質は主 にアゼラインアルデヒド酸メチルより成るすのと認めらる。

酸性物質は中和㵋 286.1 , 羷化價 542.6 にして此等の數値はアゼライン酸モノメチルエステル $\mathrm{C}_{10} \mathrm{H}_{18} \mathrm{O}$ 、

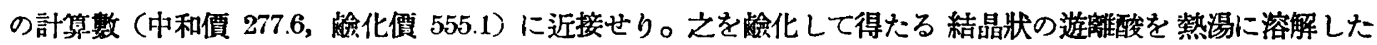
るに少許の不溶解物ありしを以て濾過し濾液を冷却してアゼライン酸の結晶を得たり。中和儹 594.9 , 融點 105 $\sim 106^{\circ} \mathrm{C}_{0}$

總括

ザクロ種子油よりエレオステアリン酸の新立體異性體なるプニカ酸（殿點 $43.5 \sim 44^{\circ} \mathrm{C}$ )を純粹の狀態に單離 し之をオジノリシスに附して分解生成物を检索せり。其結果分解生成物中に正吉草酸及アゼライン酸を確認し 又苳酸及グリオキザルも存在するものと認められたり。ヌプニカ酸メチルはオッ゙ノリシスに体りてアゼライン アルデヒド酸メチルエステル及アゼライン酸モノメチルエステルを生成せり。從てプニカ酸はエレオステアリ ン酸と同じく下記構造式を有することを知る。

$\mathrm{CH}_{3} \cdot\left(\mathrm{CH}_{2}\right)_{3} \cdot \mathrm{CH}=\mathrm{CH} \cdot \mathrm{CH}=\mathrm{CH} \cdot \mathrm{CH}=\mathrm{CH} \cdot\left(\mathrm{CH}_{2}\right)_{7} \cdot \mathrm{COOH}$

(東景工業試驗所第 2 部油脂研究室) (昭和 10 年 2 月 13 日受理)

\section{6.カラスウリ種子油中に存在する新脂肪酸 (エレオステアリン酸の新立體異性體)に就て}

\section{外山修之・土屋知太郎}

ザクロ種子油中にエレオステフリン酸の新立蹬巽性體なるブニカ酸の存在することは前報交に記載せる所な るも，其後余等は偶然の機會によりカラスウリTrichosanthes cucumeroider, Maxim. の種子油を試驗したる に此油も亦其脂肪酸の主成分としてェレオステアリン酸の新立體暴性體と認めらる〉脂肪酸を含存することを 發見せり。而して該脂肪酸が異性化によりて容易に $\beta$-エレオステアリン酸に轉位することはプ二カ酸の場合

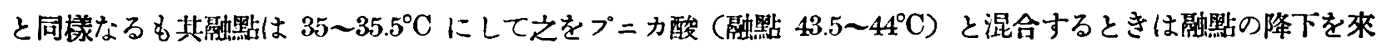
すを以てカラスウリ種子油中の脂肪酸はプニカ酸とも異る新立䯠翼性體なり。余等はカラスウり種子油中の新 立體異性體をトリコサン酸 (Trichosanic acid；Trichosansäure) と命名す。

桐油中に存在するエレオステアリン酸（壬レオステアリン酸）のほかに令包ザクロ種子油中のプニカ酸並. (47) 